\title{
The Francescanism of Ignazio Silone/ II Francescanesimo di Ignazio Silone
}

\author{
Dr. Areti Spinoula \\ Department of Italian Language and Literature, Faculty of Philosophy, \\ National and Kapodistrian University of Athens, Greece.
}

\begin{abstract}
Ignazio Silone, one of the last "maestri" of the Italian literature, the intellectual who never betrayed his conscience, will be analysed in our scientific research concerning his francescanism and how the "Poverello di Assisi" along with Francis's evangelic faith have influenced the tormented Italian writer. An old friend of the protagonist named Pierto Spina writes at Silone's novel Vino e pane: 'creare un regime all' immagine dell' uomo", isn't this, what Francis had proclaimed in his entire life, combating the human limits in order to reach his "Precious Goal"? Everyone has a goal in life and Silone achieved his through pure religious and political faith maintaining a high level of dignity throughout.
\end{abstract}

Keywords: Ignazio Silone, francescanism, Poverello di Assisi, faith, dignity.

\section{Introduction}

"La perfetta letizia non può essere che nella perfetta dedizione di sé a Dio ed agli uomini, a tutti gli uomini... La nostra vita deve essere un cantico ed un olocausto di fraternità universale in Cristo Gesü"'. Using Don Orione's words, Cardinal Angelo Sodano started his speech in the Comunità dell' Ufficio delle poste della città del Vaticano on Tuesday, March 12 in 2002. Words which take us back to the period of time when Francesco taught frate Leone about absolute happiness/"la perfetta letizia" (Fonti Francescane -FF, 2004: 1148-1149 [Fioretti]).

In order to understand Silone's Franciscanism, we need to elaborate on his relation with Luigi Orione, the Saint of our times, who taught the Franciscan ideal of God's Poor Little man of Assisi/Poverello with his life and work.

\section{The influence of Luigi Orione in the life of Ignazio Silone}

This enlightened clergyman took teenage Secondino Tranquilli -Silone's real name- after the earthquake in Marscica and instilled love of "pure" evangelical faith into him through his life and work, in a way completing the stories regarding evangelical excerpts which he heard from his mother. Orione is the personification of love. In 1915 for the first time Silone sees Luigi Orione take orphans from Pescina, which is destroyed by a massive earthquake, in order to offer them accommodation and affection. A year later, it is Silone's turn to follow Orione when the former's grandmother entrusts him to the latter's care. The writer himself gives a full account of the trip to San Remo with "this strange clergyman" as his fellow traveler. This is the night which marked his whole life and signaled the beginning of a revitalizing relation for the young traveler. The two years which he spent in Orione's schools constitute the beginning of his spiritual pursuit which lasted for his whole life. He describes the feelings aroused by the figure of this outstanding man with the following words: "Risentiro la pace nel mio cuore, il sorriso sulle mie labbra, sentirò le parole dolci del suo cuore consolato e sulla mia fronte di nuovo pura il suo sguardo umile e buono"2. Luigi Orione's steps into the world are steps of love and offer to those in need and his respect for St Francis of Assisi is reflected in his deeds throughout his life. The words cited below belong to him:

"Quando andrete nell' Umbria avrete la fortuna di andare a Greccio. lo ci fui parecchie volte.

San Francesco, tornato dalla Palestina, ancora infervorato dalla visione dei luoghi santi,

1 Available: $h$ ttp://www.vatican.va/roman_curia/secretariat_state/documents/rc_seg-st_doc_20020312_festa-beato-orione_it.html

2 Available: $\mathrm{http}: / /$ www.tracce. $\mathrm{it} /$ ?id=266\&id2=286\&id_n=9936 
volle che anche in Italia si facesse il Presepio vivente. Noi dobbiamo tornare ai primitivi tempi, al primitivo presepio, e si fa del bene" (Scritti V, 212)1.

In the 1930s, inspired by the God's Poor Little man of Assisi, he embarked on the organization of live nativy scenes for the celebration of Christmas, which was a great success ${ }^{2}$ in the very same way as Francis had done three years before his glorious death, on Christmas night ${ }^{3} 1223$ in Greccio ${ }^{4}$. Great figures like St Francis of Assisi and Luigi Orione constitute role models of social mercy/"di carità sociale". Saints are the real illuminators of history since they are men and women with faith, hope and love. This thought by Benedetto XVI (Benedict XVI, 2005), taken from the circular "Deus Caritas est", reflects Don Orione's life and work. I "I santi sono i veri portatori di luce all'interno della storia, perché sono uomini e donne di fede, di speranza e di amore". This thought of Benedetto XVI, taken from the encyclical "Deus Caritas est", presents the character of Don Orione. How could it be possible for teenage Silone not to be affected by this stance on life and not to embrace the quality of life which evangelical faith encompasses, as a pure ideologist that he was? Blessed Orione deeply influenced not only the formation of teenage Secondino Tranquilli's character but his work as well since in almost all the romanzi we perceive his figure under a different name each time. We see him in the wonderful chapter "Incontro con uno strano prete" of the narrative entitled Uscita di sicurezza, as well as in Vino e pane as "Don Benedetto", in Una manciata di more as "Don Nicola" and as "Don Serafino in II segreto di Luca. How could little Secondino not be influenced by the man who gave him his life back and led him to Jesus Christ? Silone, himself, writes:

"Avevo creduto di finirla una volta con quell'alternativa del bene e del male e mi sono disilluso. Ero come l'ubriaco caduto nel fango che vuole e non può rialzarsi e che finalmente cessa ogni sforzo e s'addormenta per terra, ma basta una lettera del prete di Tortona e non so perché quelle parole cosi ordinarie e semplici svegliarono in me la voce della coscienza (...) con una lettera nemmeno indirizzata a me, mi ha ricondotto a Gesü". (Di Nicola \& Danese, 2011: 71)

\section{The francescanism of Ignazio Silone}

Ignazio Silone was one of the greatest Italian literary men in the 20th century. All his books seem to have been written with the aim of helping the poor and those suffering in the world. In this way, Silone appears to be another Francis, always ready to stand by his beloved poor peasants/ "amatissimi suoi cafoni" as Francis stood by every hard-hit "brother". Overall, his work unmasks deception all around and within us. He describes the life of simple laborers who try, in vain, to defend what little they have left in order to survive, struggling to do so against the "suffocating reality in that era", which is the canker of every period of time. Today this is the case more than ever before. It is as if he mirrors our time and its interests which appear more threatening and full of avarice than ever, especially to the peoples of the South! In his work, love of chaste life and pure, evangelical belief in God are pervasive, freedom and love acquiring the form of generous offer sometimes even through self-sacrifice.

He expresses his objection to any form of ownership. He writes in Vino e pane that one day we will destroy evil and this will be done when we renounce any kind of ownership, which constitutes 'the dog's leash' which keeps us tied, adding that only those who have no "evil of ownership" will be redeemed ${ }^{5}$. We can see that Francis, Bernardone's son, puts the

1 Available: http://www.messaggidonorione.it/articolo.asp?ID=498

2 "The success was greater than expected" as mentioned in the newspaper article La stampa del 28.12.1932: "Successo vi è stato e grandioso e lo dimostra la folla convenuta in numero strabocchevole soprattutto dall'Oltrepò e dalla zona montana, con ogni mezzo, per vedere il presepio vivente, e si calcola che oltre 40.000 siano le persone che vi hanno assistito lungo la romana Via Emilia". The newspaper II Corriere della sera on 28.12.1932, makes mention of Don Orione with the following words: "Questo sacerdote dal nome astronomico è un tipico esempio della umana bontà senza riposi, senza ambizioni e senza enfasi. (...) Don Orione ha infine benedetto la folla che ha elevato canti e inni religiosi, conferendo alla scena un significato di viva commozione e di alta spiritualità" (vid. Peloso 2006). 3 It refers to the Christmas night in 1223. As mentioned by Bonaventura (FF, 2204: 674-675 [Leggenda Maggiore]), Francis with the Pope's assent requested that the Mass be celebrated on a "movable altar", which was uncommon at the time.

4 "Se vuoi che celebriamo a Greccio il Natale di Gesù, precedimi e prepara quando dico: vorrei rappresentare il Bambino nato a Betlemme, e in qualche modo vedere con gli occhi del corpo i disagi in cui si è trovato per la mancanza delle cose necessarie a un neonato, come fu adagiato in una greppia e come giaceva sul fieno tra i bue e l'asinello" (FF, 2004: 305-306 [Vita Prima]). 5 "L'ingordigia della proprietà è come la catena del cane. Non si salvano quelli che hanno l'ingorgigia della proprietà" (Silone,2012: 116). 
renunciation of ownership into action since he takes off all his garments and his underwear, lays them on the ground and stands naked in front of all those present, returning to his father all that belonged to him (FF, 2004: 258 [Vita prima]). This very same thrilling scene is witnessed again in L'avventura di un povero cristiano as Pope Celestino V gives up the papal throne when we see him taking off the ring, the miter, the stole and the cope, putting them on the floor next to him and putting on the simple, rough cassock of a hermit again. In the famous Fontamara, Silone writes about our times:

\begin{abstract}
"Il vero dio che ora effetivamente comanda sulla terra, il denaro. E comanda su tutti, anche sui preti come don Abbachio, che a parole predicano il Dio del cielo. La nostra rovina, aggiungeva Berardo, forse è stata di aver continuato a credere al vecchio dio, mentre sulla terra regna un altro".
\end{abstract}

In his first book, he unfolds his faith in life and religion, both away from secular interests. He seeks simplicity purity in both interpersonal relations and his contact with the divine factor. In his book Vino e pane, he mentions:

\begin{abstract}
"Nel catechismo, che da ragazzo mi hanno fatto imparare a memoria, stava scritto: le opere di misericordia sono, dare da bere agli assettati, vestire gli ignudi, ricoverare i pellegrini, curare gli infermi [...] Non c'era scritto, curare gli infermi che la pensano come te. C'era scritto curare gli infermi, senz'altro. Non so se mi sbaglio". "Per Cristo bisognerebbe aiutarli".
\end{abstract}

An offer to all making no distinction. This is what was taught by Francis, who mistrusted the educated but who opened his heart without any reservation to the outcast, the poor, the thieves. At the beginning of the Rule of the Order, he inscribed "Every human who comes to their brothers, friend or enemy, thief or robber should be accepted with kindness" (Joergensen, 1951: 165). In Specchio di perfezione (FF, 2004: 1064 [Specchio di Perfezione]), a relative incident which concerns the early years of the Order is mentioned and he relates the service offered to thieves by the frati minori that lived in the retreat of San Sepolcro ${ }^{1}$ which resulted in their repentance and, for a number of them, their induction into the Order.

In romanzi Fontamara, il Segreto di Luca, Vino e pane, there is a 'fellow traveler', devoted to the hero, just as frate Leone was a loyal friend, companion and fellow traveler of St Francis. Luca, Berardo and Pietro Spina are human beings ready to live and die for noble ideas or deep love; people beyond reproach with a strong sense of duty for the others and the society they dream about. Next to them always stand an anti-conformist clergyman -for Silone, one such guardian angel was Don Orione 'his own anti-conformist clergyman'- and a woman who platonically admires their integrity and their principles, as Santa Chiara ${ }^{2}$ admired and respected the man who gave meaning to her being and opened her road to a life next to Jesus Christ, God's Poor Little man of Assisi.

In Vino e pane, there are multiple references to St Francis of Assisi. Among the most typical ones, we can mention that of the hero don Paolo/Pietro Spina conversing with birds:

"Intanto una flotta di passeri e qualche colombo selvatico gli saltellavano e svolazzavano attorno come in un'uccelliera. Ad alcune donne che osservavano la scena da lontano, parve, ad un certo momento, ch'egli parlasse con i volatili [...] "il tuo prete" esse dissero a Matalena "conversa con gli uccelli, come San Francesco".

In the famous work L' avventura di un povero cristiano, we find Matteo asking Concetta if she converses with birds: "Concetta che fai? Parli con gli uccelli?" Scenes which bring to mind the Prayer to birds by St Francis/predica agli uccelli di San Francesco. (FF, 2004: 289 [Vita prima]).

Next, we have fra Gioacchino's self-characterization: I am God's Ass/ "Sono un asino del Signore”, a simile used by St Francis when he referred to his body as a brother ass/"fratello asino"(Joergensen, 1951: 155-156). Divine Providence constitutes a basic element in Silone's romanzi. Expressions such as God will give it to us/ "Dio provvederà", Providence has sent you/ " $E$ ' la provvidenza che vi ha mandato" disse, baciandogli la mano", an inspiration from Providence/ "un' ispirazione della Provvidenza" are found in all 4 romanzi and as we all know Providence was the foundation stone in Francis' life. The greeting "Pax vobiscum" (Silone, 2007: 79) which is met in II Segreto di Luca constitutes a paraphrase of, God

1 It is the monastery on mount Casale.

2 For more information on the personality and life of Santa Chiara, vid. Spinoula (2008b, 2014). 
give you peace/ "Il Signore ti dia la pace" (FF, 2004: 101 [Testamento]) by San Francesco. In L'avventura di un povero cristiano is heard the Franciscan greeting "Peace is with you"/ "La pace sia con voi tutti" (Silone, 2013: 66). Silone's heroes are all good Christians, with the evangelical meaning of the term Christian; people who hold no grudge and who are led in life by unselfishness, love and offer to those around them and society, as a whole; people who lead a difficult life, with hardships though free from meanness or malice, which poison one's soul; people who are unshakable in their faith in a broader sense, indicating the unshakable belief and interminable struggle for a noble aim which leads them to catharsis. All of them -Luca, Berardo, Pietro Spina and most of all Celestino V- are little Francis; pure and, at the same time, strong personalities, unreconciled with the social and the religious status quo of their times. In Vino e pane, Cristina's discovery is fundamental; she ascertains that intellectual life cannot be compatible with a life full of security. In order to be saved, one has to take risks/ "Vita spirituale e vita sicura non stanno assieme. Per salvarsi bisogna rischiare".

In his work L'avventura di un povero cristiano, a narrative that turns out to be regarded as a sort of instruction, Silone's ideology regarding religion unfolds in front of us. The environment in which the main characters move is clearly Franciscan; on the other hand, the figures of authority apparently insulted the intellectual inheritance of the God's Poor Little man of Assisi.

In the introduction of his book, Silone states that his Christianity is due primarily to his family. He shares the evangelical parables which his mother narrated to him during his childhood and his teenage years with us and admits that he does not hesitate to believe rebels are more devoted to Jesus Christ.

He starts his narration admitting that he first visited those places with his family on a pilgrimage and he argues that he does not know to what extent the stories and the eulogies for saints/martyrs which he heard at a tender age touched him and formed his way of thinking. The region from the middle ages to the end of the $18^{\text {th }}$ century was the place of the "spiriti eletti" and proved to be the place which housed and supported the fraticelli detti spirituali, when they distanced themselves from the francescani conventuali. Silone, himself, states that it was the land of the chosen and that of utopia. If utopia has not died/got lost either from religion or politics, it is because it answers a deep human need/ ' $E$ stata la terra di elezione dell' utopia. Se l' utopia non si è spenta nè in religione, nè in politica, -afferma lo stesso Silone-, è perchè essa risponde a un bisogno profondamente radicato nell' uomo" (Silone 2013: 23).

L' avventura di un povero cristiano is Ignazio Silone's only work whose plot does not refer to the contemporary political reality. However, this is only superficial. In reality the only thing this outstanding literary man is interested in is to reveal personalities who fight for freedom and dignity against any form of violence. And franciscanism constitutes a form of revolt.

The book is a praise of fraticelli spirituali. Many personalities of spirituali are mentioned in it, such as Pietro da Fossocombre renamed Angelo Clareno and Jacopone da Todi. The spirituali's struggle unfolds in its pages and reminds us of San Francesco's struggle against frate Elia.

Frate Ludovico characterizes frate Elia "infame" in Silone's work:

FRA LUDOVICO: Le sue parole (cioè quelle di San Francesco) furono tradite prima ancora che lui morisse, dall' infame frate Elia, con l'appoggio del papa e dei vescovi. Nel concetto francescano della povertà essi vedevano un pericolo per i loro privilegi e quelli delle loro famiglie.

DON CONSTANTINO: La regola del 1223 contiene precetti più ragionevoli. Perchè non seguite quelli?

FRA LUDOVICO: Vi furono inseriti contro la volontà di San Francesco. La testimonianza di frate Leone non lascia dubbi in proposito. II Poverello ne rimase ferito a morte.

In reality, frate Elia was the means which opened the road to fratelli conventuali. Francis' animosity towards Elia was such that he answered the following when the latter asked him where his enmity derived from: "La cagione si è questa, imperò che a me é suto rivelato da Dio che tu per i tuoi peccati apostaterai dell'Ordine e morrai fuori dell'Ordine, e anche m'ha Iddio rivelato che tu sei dannato" (FF, 1986: 945 [Fiorett]) 
Aiming to reveal why, in our opinion, Silone got engaged in writing this work, at this point we should make mention of what frate Elia represented for the franciscan spirit. Silone ardently supported the purest expression of the Christian belief, the belief in Jesus Christ's steps as experienced in life by Poverello and as expressed by the fratelli spiriruali, the people who continued Francis' intellectual inheritance 1 . He fights against the source of all evils, which is the temptation of power, and has aligned himself with Celestino's statement against Bonifazio's arrogance: in this deplorable century the honor to bear the name of Christian has been bestowed on "those poor creatures"/ "in questo triste secolo, l'onore del nome cristiano sia affidato a quei poveretti" by God. The war the conventuali declare against humbleness is Silone francescano's war against the arbitrariness of authority. Frate Elia represents this arbitrariness within the Order. Understanding the contrast between Francis and Elia will help us comprehend the problem of discord which Silone examines and which constitutes his cry of anxiety.

There are multiple accusations against frate Elia and they come from different sources ${ }^{2}$. The 13 accusations of Salimbene (vid. Dallari, 1970?: 49) are well-known. Ubertino (Dallari 1970?: 50), who writes in 1305, places frate Elia against the will of St Francis and presents him as "spiritus diaboli", as "frate superbo" and as "un bastardo dell'Ordine"3. Giano, Eccleston kaı Salimbene accuse Elia mainly of despotism. For Speculum Vitae, Elia "maximam destructionem Regulae praetendebat" (Dallari, 1970?: 50) does not do anything else but transgress sacred poverty.

Frate Elia disagreeing with the Rule which Francis wrote visited him in Monte Colombo where the saint was with frate Leone, his loyal companion and frate Bonizo da Bologna in order to draw up the Rule of the Order. He went along with the other ministri who belonged to the subsequent movement of the conventuali, with the aim to dissuade him from drawing up a strict set of rules and regulations. Francis, then, as mentioned in Leggenda Perugina confronted him saying:

«Francesco usci e vedendo i ministri chiese: "Cosa vogliono questi fratelli?"

Rispose Elia: "Sono dei ministri. Venuti a sapere che stai facendo una nuova Regola e temendo che sia troppo aspra, dicono e protestano che non intendono essere obbligati. Scrivila per te, e non per loro".

Francesco levò la faccia al cielo e parlò a Cristo: "Signore, non lo dicevo che non ti avrebbero creduto?" E subiti si udi nell'aria la voce di Cristo: "Francesco, nulla di tuo è nella Regola, ma ogni prescrizione che vi si contiene è mia. E voglio sia osservata alla lettera, alla lettera, alla lettera! Senza commenti, senza commenti, senza commenti". Aggiunse: "So ben io quanto può la debolezza umana, e quanto può la mia grazia. Quelli dunque che non vogliono osservare la Regola, escano dall' Ordine!".

Si volse allora Francesco a quei frati e disse: "Avete sentito? Avete sentito? Volete che ve lo faccia ripetere?"».

\section{(FF, 1986: 859 [Leggenda perugina])}

Angelo Clareno4, the name given to Pietro da Fossocombre after the foundation of the religious group of the "Pauperes heremite Domini Celestini" extensively refers to Silone's work, as Silone is the person who genuinely continues San Francesco's work and as the intimate and like-minded friend of Pope Clemente V. Angelo Clareno claims that Elia is nothing

\footnotetext{
1 Vid. Spinoula (2009) about Francis' worldview on poverty.

2 Vid. Spinoula (2008a).

3 "Un bastardo dell'Ordine" as Francis himself called him: "Helia, Helia, tua fastosa pompositas et carnis prudential et tui similium ordinem meum ducent ad nihilum et totam paupertatem evangelici spiritus evacuabunt". Because God wanted him to be the Vicario of the Order, the sweet God's Poor Little man of Assisi felt compelled to say: "Sed stupendum est de isto Deo qui talem te cognoscit et vult quod in tuis minibus ordinem derelinquam".

4 Clareno (FF, 2004: 1424-1425 [Libro di tribolazioni]) says: "Questi é mio servo Francesco che mi sono scelto e ho posto in lui il mio spirito. Gli ho domandato di fare quanto ha fatto e di scrivere la Regola che sta scrivendo; la vita e Regola che scrive è mia e viene da me, non da lui. Chi ascolta lui, ascolta me; chi disprezza lui disprezza me. A coloro che chiamerò a osservare questa vita e regola, conferirò lo spirito di fortezza per osservarla. Ma voglio che questa Regola sia osservata ala lettera, alla lettera, alla lettera".
} 
but a heretic and distorter of the franciscan spirit and that his sanctity is fake like his relation with their Francis. He ends by saying that he is a subverter':

His opposition to the Rule of the Order is perceived in the famous Capitolo generale delle Stuoie, in which 5,000 brothers and Cardinal Ugolino, later Pope Gregorio IX, participated. Most of the participating brothers were educated and belonged to the progressive, renamed conventuali. They were the ones who asked Ugolino to put pressure on Francis to accept to be guided by them who were educated so that they could lead a life based on the Rule of other Orders. Francis, however, remained adamant and replied with the following words:

"Fratelli, fratelli miei, Dio mi ha chiamato a camminare la via della semplicità e me l' ha mostrata. Non voglio quindi che mi nominate altre Regole, nè quella di sant' Agostino, nè quella di san Bernardo o di san Benedetto. II Signore mi ha rivelato essere suo volere che io fossi un pazzo nel mondo: questa è la scienza alla quale Dio vuole che ci dedichiamo! Egli vi confonderà per mezzo della vostra stessa scienza e sapienza. lo ho fiducia nei castaldi del Signore, di cui si servirà per punirvi. Allora, volenti o nolenti, farete ritorno con gran vergogna alla vostra vocazione".

Stupi il cardinale a queste parole e non disse nulla, e tutti I frati furono pervasi da timore».

(FF, 1986: 860 [Leggenda Perugina])

Elia schemes to oust Francis from the leadership of the Order and he deceitfully seizes the Rule from frate Leone's safe keeping, writes Clareno (as cited in Dallari, 1970?: 50-51). On top of that, Clareno continues that Elia arbitrarily teaches things differently from what Francis loved and taught and deliberately made much of what he had heard and seen from the founder of the Order of Lesser Brothers sink into oblivion (FF, 2004: 1431 [Libro di tribolazioni]).

Sabatier (1904), on the other hand, implies that frate Elia's missionary zeal is perhaps due to his personal interest in removing all the brothers who were attracted to adventure and were less devoted to his authority. What is important is that he succeeds in changing the balance within the Order.

Fra Pietro di Angelerio, who later became Pope Celestino V, ardently advocated the spirituali, who were persecuted by the religious authorities, and gave them refuge. More specifically, as far as Pietro da Fossocombre is concerned, Silone writes: "Egli viene iniziato alla coscienza del pensiero autentico di San Francesco, dal suo discepolo più caro e fedele, frate Leone. Per questo voi lo odiate e lo perseguitate come un bandito" (Silone, 2013: 58).

In parenthesis, at this point let us confirm what frate Leone, who was Francis' intimate friend and ardent supporter of divine poverty, said. He is the only one to whom Francis left a written blessing, in which Tau-croce cuts Leone's name in half pointing out that he belonged to the chosen, "segnati in fronte dal segno della salvezza" (Cf. Ez 9,4; Ap 7,1-10).

The blessing to frate Leone/ Benedizione a frate Leone, in the original text is the following:

«ll Signore ti benedica e ti custodisca;

Mostri a te il suo volto e abbia misericordia di te.

Rivolga il suo volto verso di te e ti dia pace».

(FF, 2004: 177 [Benedizione a frate Leone])

Frate Leone writes a second red-ink title just under Francis' blessing:

1 "Subtilitatibus philosophiae frater Helyas deditus, qui secrete post se trahebat catervam subversorum a spiritu cupiditatis et vanitatis, et sibi ipsi aperiebat lacum et fodiebat et quia seductus incidit et defecit. Nec intelligebat consilia et astutias et adibventiones Sathanae, quibus ignorans per alias vias et expediebat itinera et semitas dirigebat, Christo in fundatore repugnans..." (Clareno, as cited in Dallari, 1970?: 50). 
«ll beato Francesco scrisse di sua mano questa benedizione a me, frate Leone:

"Il Signore benedica te, frate LeTone"

(FF, 2004: 177 [Benedizione a frate Leone])

Under the point of Tau (T), there is a third red-ink title by frate Leone: "Allo stesso modo fece questo segno thau col capo, di sua mano"1.

As far as Pietro da Fossocombre is concerned, Silone mentions that fra Pietro di Angelerio had just decided to accept the papal throne and, while he was still in his hermitage, San Onofrio on mount Morrone, he called his confidant fra Ludovico, asking him to inform him as well as some more people of his absolute trust at once, so that they wait for him in Aquila because he was in dire need of them (Silone, 2013: 96).

Thus, we see that Silone focuses on the special relation between the two men, a relation that they both served faithfully and with fervor. For his part, fra Pietro as Pope Clemente $V$ decided to integrate Pietro da Fossocombre into a new brotherhood named di "pauperes eremitae", so as to put an end to the persecution he underwent. Thus, Clareno and his followers lived in a hermitage, far away from the conventuali.

The new pope, Pope Clemente V, unfolds his personality in Silone's work L' avventura di un povero cristiano. It is an evangelical personality, free from the ambition of secular authority and luxury that his office offers him. He is presented as a real hermit, as the person who continues the evangelical poverty, as the ardent supporter of the Franciscan ideal when it comes to both his dress, which is described as remarkably simple since he wears only a white cassock and has a wooden cross around his neck/"Egli veste un semplice camice bianco e reca appeso al collo un piccolo crocifisso di legno"(Silone, 2013: 99), and to his everyday habits.

When he lived in his hermitage, he was in the habit of playing and talking with the animals. He spoke with a fox he called "suor Giuseppina", a snake he called "suor Concettina" and a cricket he called "don Cicillo". Just as Francis he said: "fratelli miei uccelli", "sorelle mie rondini", "fratello leprotto", "fratello pesce" (FF, 2004: 290-291 [Vita prima]), "frate lupo" (FF, 2004: 1170 [Fioretti]), "frate fagiano" (FF, 2004: 473 [Vita seconda]) and as Celano mentioned in "Vita prima", he called all the creatures with the name brother or sister/ "chiamava tutte le creature con il nome di fratello o sorella" (FF, 2004: 303 [Vita prima]). Silone finds one more similarity between Francis and fra Pietro as, according to his companions fra Bartolomeo, fra Angelo and fra Ludovico, it is unthinkable to interrupt him during his prayers even if it is the king himself who is calling him. We ought to note at this point that it is no coincidence that the writer of $L^{\prime}$ avventura di un povero cristiano places 3 companions next to fra Pietro. It is a parallelism with Francis' three companions Leone, Ruffino and Angelo. In addition, frate Bartolomeo's admitted that many times when the Saint of Morrone prayed, the mountain was wrapped in a pure, supernatural light. Joergensen in his "St Francis of Assisi" cites the same. He writes that when Francis prayed in the forest, he was wrapped in a sparkle. (Joergensen, 1951: 260).

After that, Silone has fra Pietro di Angelerio ardently support the purity of the Franciscan teachings with the following words: "E l'interesse dell'intera cristianità che l'insegnamento di San Francesco sia salvaguardato in tutta la sua purezza". As a Pope, he then tries to convey this superficial simplicity of the teaching which hides the greatness of the holiness inside itself to the friars who are presented by Silone to be annoyed, with these words: "L' intera esistenza di un cristiano, [...., ha appunto questo scopo: diventare semplice" and he continues: "Il cristianesimo infatti non è un modo di dire, ma un modo di vivere". In these two sentences, however, the life and the work of the God's Poor Little man of Assisi are summarized.

He tried to continue this simple life even after his enthronement. Nevertheless, we see that he becomes an object of derision and mockery by the cardinals and the papal court.

1 Between the second and the third red-ink title, in the parchment, there is a drawing with a big cross in the shape of Tau, planted on a mountain roughly outlined, in which there seems to be a head wearing a headpiece wrapped in a turban. As mentioned in Leggenda aurea by Jacopo da Varace (FF, 2004: 177 [Lodi di Dio Altíssimo]), the Tau is Jesus Christ's cross planted on Adam's grave and symbolizes the redemption of all the mankind. The cross shaped in Tau cuts Leone (LeTo) in order to signify that this particular brother belongs to the chosen who have the sign of salvation on their forehead. 


\section{Conclusion}

The dual nature of the Catholic Church is embodied in the two main characters of the work: Pope Celestino $V$ and Cardinal Caetani, who afterwards ascended the papal throne as Pope Bonifazio VIII. While Celestino puts the Word of God into practice, cardinale Caetani sees church as a political party which, in return, asks its supporters not for their vote but for their soul. We could go even further and assume that we are all Pope Celestino, all of us who still believe in ideals and values. Certainly, the writer himself, Silone, is one of them. On the other hand, we have the Bonifazi of this world with Pharaonic behavior, who are pitiless, in their effort to prove that a battle against them would be catastrophic. In this unequal battle, Silone's Christianity is emphasized as love for the less privileged of this life, a kind of Christianity in conjunction with socialism as a service to man, not as a political power focusing on the privileges of state power.

We all wish the bitterness expressed in Silone's note: the usual story/"la solita storia" 40 when he sent L'avventura di un povero cristiano to his editors in March 1968 to be converted into happiness and enthusiasm in people's souls as described to us by Petrarch in De vita solitaria: "La gioia e l'entusiasmo della sua discesa testimoniano quanto l'ascesa fosse stata triste e contaria alle sue aspirazioni. Da persone che lo videro ho sentito dire ch' egli fuggi con immensa gioia, portando negli occhi e nel volto $i$ segni della sua letizia spirituale, quando, libero finalmente e restituito a se stesso, si allontanò dal concilio quasi avesse sottrato non le spalle a un peso moderato, ma il collo a una terribile scure, sicchè risplendeva, nel volto di lui, non so che luce angelica. E non a torto: ben sapeva infatti che cosa andava a trovare, e non ignorava quel che lasciava. Dalle fatiche ritornava al riposo, dalle discussioni inutili ai colloqui divini, abbandonava la citta, andava con l'animo e -se l'astuzia del successore non vi si fosse opposta- andava con il corpo su di una montagna aspra e scoscesa, lo ammetto: ma di là gli si sarebbe aperto facile il cammino fino alle cose celesti. Oh magari fossi vissuto con lui!"(Silone, 2013:228-229)

\section{Bibliography}

[1] BENEDICT XVI (2005), "Deus caritas est", Encyclical letter of the Supreme Pontiff. Roma: Libreria Editrice Vaticana. [Online]. Available: $h$ ttp://w2.vatican.va/content/benedict-xvi/en/encyclicals/documents/hf benxvi_enc_20051225_deus-caritas-est.html

[2] DALLARI, P. (1970?), Frate Elia architetto della basilica d'Assisi e di Cortona. Milano: Unione editoriale italiana.

[3] DI NICOLA, G.P. \& A. DANESE (2011), Ignazio Silone: Percorsi di una coscienza inquieta. Cantalupa (Torino): Effatà.

[4] Fonti Francescane [FF], Editio Minor (1986). Assisi: Editrici Francescane.

[5] Fonti Francescane [FF], Nuova edizione (2004). Assisi: Editrici Francescane.

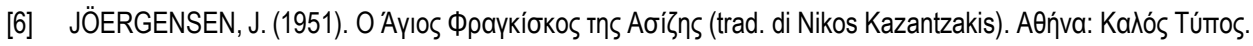

[7] PELOSO, F. (2006, 6/1), "San Luigi Orione. Promotore dei presepi viventi", in L'Osservatore Romano, p.5. [Online]. Available: http://www.messaggidonorione.it/articolo.asp?|D=498\#ok

[8] SABATIER, P. (1904). Examen de la vie de Frère Elie du Speculum Vitae suivi de trois fragments inèdites, in Opuscules de critique historique, XI, 127-311.

[9] SILONE, I. (1988). Fontamara. Milano: Mondadori-Oscar classici moderni.

[10] SILONE, I. (2007). II segreto di Luca. Milano: Mondadodri-Oscar classici moderni.

[11] SILONE, I. (2012). Vino e Pane. Milano: Arnoldo Mondadori.

[12] SILONE, I. (2013). L'avventura di un povero cristiano. Milano: Mondadodri-Oscar classici moderni.

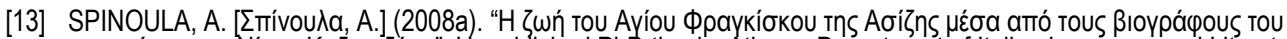

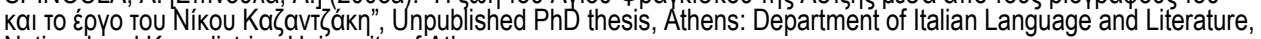
National and Kapodistrian University of Athens.

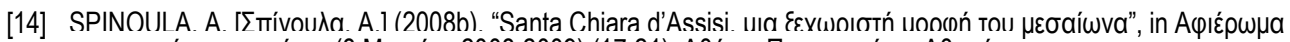

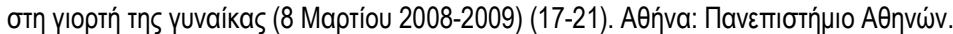

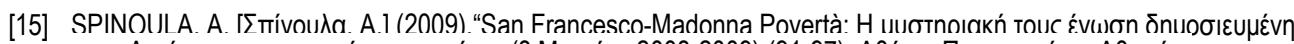

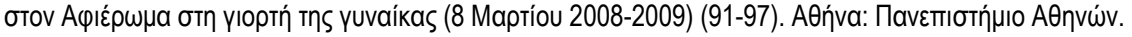

[16] SPINOULA, A. (2014). "La 'Chiara' di N. Kazantzakis, mito e realtà". In E. Gonzalez de Sande \& M. Gonzalez de Sande (Eds.), Mujeres en guerra / Guerra de mujeres en la sociedad, el arte y la literatura (electronic format). Sevilla: Arcibel editores. 